\title{
Seroprevalence of BHV-1 (bovine herpesvirus type 1) among non-vaccinated dairy cattle herds with respiratory disorders
}

\author{
K. Rypuła ${ }^{1}$, K. Płoneczka-Janeczko ${ }^{1}$, J. Kita ${ }^{2}$, A. Kumala ${ }^{1}$, \\ J.F. Żmudziński ${ }^{3}$ \\ ${ }^{1}$ Division of Infectious Diseases and Veterinary Administration, Department of Epizootiology with Clinic of \\ Birds and Exotic Animals, Faculty of Veterinary Medicine, \\ University of Environmental and Life Sciences, Pl. Grunwaldzki 45, 50-366 Wrocław, Poland \\ 2 Division of Infectious Diseases and Epidemiology, Department of Large Animal Diseases with the Clinic, \\ Faculty of Veterinary Medicine, Warsaw University of Life Sciences - SGGW, \\ Nowoursynowska 159c, 02-776 Warsaw, Poland \\ ${ }^{3}$ Department of Virology, National Veterinary Research Institute, Al. Partyzantów 57, 24-100 Puławy, Poland
}

\begin{abstract}
The objective of this study was to estimate a herd-level seroprevalence of bovine herpesvirus type 1 (BHV-1) in herds with clinical symptoms of the respiratory tract. Eighty-three herds with suspected BHV-1 infection were selected and divided into two categories with respect to their size: small $(n=27)$ and large herds $(n=56)$. Samples were collected from calves, heifers and cows older than 24 months. Seroprevalence was determined using the gB ELISA test. The herd level seroprevalence was estimated as $53 \%(44 / 83)$ in the tested herds, $11.1 \%(3 / 27)$ in the small herds and $73.2 \%(41 / 56)$ in the large herds. Our study suggests that the current biosecurity measures still warrant improvement.
\end{abstract}

Key words: BHV-1, herd-level seroprevalence, seroconversion, ELISA, dairy cattle

\section{Introduction}

In the light of the earlier studies, conducted in Poland by Rola et al. (2011) seroprevalence of BHV-1 was $20.6 \%$ in $1996-1998$ and $37.7 \%$ in $2004-2005$. The aim of our study was to determine a herd-level seroprevalence of BHV-1 in dairy cattle herds with respiratory disorders, suspected of BHV-1 infection.

\section{Materials and Methods}

The study was conducted in 83 dairy cattle herds (Holstein-Friesian) under a veterinary supervision of the Faculty of Veterinary Medicine in Wrocław (Poland). In all farms the owners observed clinical problems with the respiratory tract (suspicion of BHV-1 infection). The study was conducted in two types of 
Table 1. Description of herds tested.

\begin{tabular}{cccccc}
\hline & $\begin{array}{c}\text { No. of herds } \leq 100 \text { cows } \\
(\mathrm{n}=27)\end{array}$ & & \multicolumn{2}{c}{$\begin{array}{c}\text { No. of herds }>100 \text { cows } \\
(\mathrm{n}=56)\end{array}$} \\
\hline Animals & Age & Total count & Animals & Age & Total count \\
\hline Calves & $<6$ months & 199 & Calves & $<6$ months & 464 \\
Heifers & $6-12$ months & 215 & Heifers & $6-12$ months & 548 \\
Cows & $>24$ months & 270 & Cows & $>24$ months & 560 \\
\hline Totals & & 684 & Totals & & 1572 \\
\hline
\end{tabular}

Table 2. Results obtained in small and large herds $(n=83)$, in three age categories.

\begin{tabular}{|c|c|c|c|c|c|}
\hline \multirow[b]{2}{*}{ Herds } & \multirow{2}{*}{$\begin{array}{l}\text { Positive calves } \\
<6 \text { months }\end{array}$} & \multirow{2}{*}{$\begin{array}{c}\text { Heifers } \\
\text { 6-12 months }\end{array}$} & \multirow{2}{*}{$\begin{array}{c}\text { Cows } \\
>24 \text { months }\end{array}$} & \multicolumn{2}{|c|}{ Status of the herd } \\
\hline & & & & Seropositive & Seronegative \\
\hline $\begin{array}{c}\leq 100 \text { cows } \\
(n=27)\end{array}$ & $\begin{array}{l}199 \text { tested } \\
20 \text { positive }\end{array}$ & $\begin{array}{l}215 \text { tested } \\
5 \text { positive }\end{array}$ & $\begin{array}{l}270 \text { tested } \\
28 \text { positive }\end{array}$ & 3 & 24 \\
\hline $\begin{array}{c}>100 \text { cows } \\
(\mathrm{n}=56)\end{array}$ & $\begin{array}{l}464 \text { tested } \\
311 \text { positive }\end{array}$ & $\begin{array}{c}548 \text { tested } \\
167 \text { positive }\end{array}$ & $\begin{array}{l}560 \text { tested } \\
370 \text { positive }\end{array}$ & 41 & 15 \\
\hline
\end{tabular}

herds: small ( $\leq 100$ cows) and large ( $>100$ cows) in three age categories (Table 1). No vaccinations against BHV-1 was performed. Number of serum samples to be collected to confirm the presence of the disease in each animal category was calculated with the Episcope 2.0 software at the assumption of prevalence at the level of $50 \%$ and confidence at the level of $95 \%$. Antibodies against BHV-1 were detected using an ELISA test (HerdCheck BHV-1 gB, IDEXX, Scandinavia AB, Sweden) according to the manufactures instruction. A herd was declared positive when at least one animal turned out positive irrespectively of the age category to which it belonged.

\section{Results}

Antibodies against BHV-1 were detected in 44 $(53 \%)$ of the herds tested. Seroprevalence in the small and the large herds was $11.1 \%$ and $73.2 \%$, respectively. The overall percentage of seroconversion was $39.93 \%$ among the animals examined $(n=2256)$. The prevalence ratio was 6.59 (95\% Confidence interval: $2.24-19.38)$. The detailed results are shown in Table 2.

\section{Discussion}

Bovine Herpesvirus type 1 (BHV-1) is one of the major pathogens involved in respiratory and reproductive problems of cattle. It is a type of latent infec- tion, where the latency follows primary infection (Lemaire et al. 2000). Herd-level seroprevalence s determined according to specific criteria for the classification of such herds as positive. In Ireland the BHV-1 herd-level seroprevalence was $74.9 \%$ and in England 42.3\% - 40.0\% (Woodbine et al. 2009, Cowley et al. 2011). Our results were similar (53\%), however the herd-level seroprevalence was significantly lower in smaller herds $(11.1 \%)$ compared to large ones (73.2\%). The association between the size of herd and seroprevalence was comparable to that reported in other countries e.g. England (Cowley et al. 2011) or Estonia (Rapeeri et al. 2010). It is possible that this tendency results from different herd management. Also, our results confirmed the differences in seroprevalence in different age groups, comparable to those reported in cattle in Germany, Italy and Hungary by Makoschey et al. (2007). From the standpoint of the current legislation, compulsory monitoring of BHV-1 infection in Poland was commenced last year (Regulation of the Minister of Agriculture of 24 June 2010, Journal of Laws 2010, No. 123). The national compulsory IBR eradication programme still needs supplementing. Moreover specific immunoprophylaxis has been allowed in Poland since 2005 (Makoschey et al. 2010). Despite the fact that herd-level seroprevalence has slightly decreased after implementation of a marker vaccine, the current biosecurity measures like introduction of only seronegative new animals or restrictions in animal movement, still warrant improvement of the status of animals. 


\section{References}

Cowley DJ, Clegg TA, Doherty ML, More SJ (2011) Aspects of bovine herpesvirus-1 infection in dairy and beef herds in the Republic of Ireland. Acta Vet Scand 53: 40-43.

Lemaire M, Veynants V, Godfroid J, Schynts F, Meyer G, Letesson JJ, Thiry E (2000) Effects of bovine herpesvirus type 1 infection in calves with maternal antibodies on immune response and virus latency. J Clin Microbiol 38: 1885-1894.

Makoschey B., Franken P., Mars J.M.H., Dubois E., Schroeder C., Thiry J., Álvarez M., Rypula K., Cavirani S., Arnaiz I., Houtain J.Y., Bartak P., Brownlie J., Wolf G., Meyer G., Klee W., Beer M., Moennig V., Thiry E. (2010) IBR and BVD control: the key to successful herd management. Berl Münch Tierärztl Wschr 123: 519-521.
Makoschey B, Zehle HH, Bussacchini M, Valla G, Pálfi V, Földi J (2007) Efficacy of a live bovine herpesvirus type 1 marker vaccine under field conditions in three countries. Vet Rec 161: 295-298.

Raaperi K, Nurmoja I, Orro T, Viltrop A (2010) Seroepidemiology of bovine herpesvirus 1 (BHV-1) infection among Estonian dairy herds and risk factors for the spread within herds. Prev Vet Med 96: 74-81.

Rola J, Socha W, Żmudziński JF (2011) Determining the genotype of bovine herpesvirus 1 strains isolated from cattle in Poland. Medycyna wet 67: 125-128.

Woodbine KA, Medley GF, Moore SJ, Ramirez-Villaescusa AM, Mason S, Green LE (2009) A four year longitudinal sero-epidemiological study of bovine herpesvirus type-1 (BHV-1) in adult cattle in 107 unvaccinated herds in south west England. Vet Res 5: 5. 